\title{
Strengthen the Legal Education of College Students and Maintain the Safety and Stability of Campus
}

\author{
Meng Zhu \\ Heilongjiang University of Technology, Jixi, Heilongjiang, China, 158100 \\ Email: hljzm@163.com
}

Keywords: Higher education; Legal education; Harmony and stability

\begin{abstract}
Civic education is an important part of the education all over the world, and its core is legal education, which is an important means to guide citizens to conduct harmonious and orderly social life. As the national base for training talents of high quality and professional skills, colleges and universities are the cradle for training social builders. The development of legal education is of great significance in building good teaching environment and maintaining social stability and harmony in the future. In this paper, the social value and significance of the legal education of college students are analyzed and discussed.
\end{abstract}

\section{Introduction}

\subsection{The goal of college students' legal education.}

With the continuous advancement of the national legal work, the achievements in the construction of a society ruled by law are increasingly plenteous. In order to achieve the goal of national legal system, legal education is first carried out in colleges and universities. The legal education of college students is mainly in the form of classroom law popularization, with the purpose of achieving the following goals in education:

Train qualified social citizens. Civic education has always been one of the contents of education in various countries, with the purpose to cultivate the civil awareness of citizens, that is, awareness of participating in social politics and economy, awareness of supervising the operation of state power, awareness of fulfilling state and social responsibilities, and legal awareness of law and usage. Qualified social citizens are the motive power for the development and progress of the society and the country, and the embodiment of a country's comprehensive national strength.

Cultivate legal concepts and legal awareness. The direct manifestation of legal education is to enable students to comply with the requirements of laws and regulations in real life, understand the basic principles and significance of laws, understand basic legal knowledge, and know that they can take up legal weapons to protect themselves when their own interests are harmed.

Standardize daily behaviors. The performance of legal education in daily life is to make students take the law as the criterion to measure whether their behaviors are within the scope stipulated by the law and to resolutely avoid behaviors outside the scope stipulated by the law.

\subsection{The significance of college students' legal education.}

The legal education, which has been incorporated into the daily teaching courses of colleges and universities, is closely related to the study, life and other activities of college students.

It is conducive to the construction of the safe and harmonious campus environment. From the interface point between students and social identity, college students' own world view, values and outlook on life have been completely established. Carrying out legal education on college students can make them put their own ideology under the legal consciousness and prevent the occurrence of situations that endanger campus safety. At the same time, college students are under the double pressure of study and employment, and their mental health is prone to problems. Timely legal education can alert students to these problems so as to avoid irreparable consequences.

It is conducive to the cultivation of college students' comprehensive quality. During the study 
period in institutions of higher learning, students not only need to have rich scientific and cultural knowledge, good moral quality, the ability to actively learn, the ability to communicate and cooperate with others, healthy physique and psychology, etc., but also need to have higher legal awareness. Only student with comprehensive qualities can be a sound social person, who can adapt himself to the development of society, better integrate into society and realize their own development.

It is conducive to the dissemination and popularization of legal knowledge. The 21st century is a society with highly developed information, in which information flows and spreads rapidly. As active communicators of new ideas, students can spread the legal education received in schools through teaching, practice, discussion and other channels to achieve certain popularizing-law effect.

\section{Current situation of legal education in colleges and universities}

The development of legal education in colleges and universities has a history of nearly 30 years, and students' awareness of the rule of law and legal concepts have also been improved. However, there are still many problems in the current legal education in colleges and universities, which affect the effect of legal education for college students.

\subsection{The boundary between moral education and legal education is not clear.}

In China's legal education, the learning of legal knowledge, compliance with laws and regulations and other content are still divided into social moral education. The education of legal content is also carried out as part of social moral education, which makes legal education lack independence and leads teachers and students to neglect the importance of legal education. Such legal education is not effective or meaningful.

\subsection{The concept of legal education is backward.}

Legal education is an important part of civic education, and the formation of citizen consciousness is of great significance to the country and society. However, civic education is still in its infancy in China, and it has not been paid much attention by the society and colleges and universities. Therefore, when conducting legal education in colleges and universities, the textbooks and cases used are seriously lagging behind, and the concept of legal education with the goal of law popularization lags far behind that of other countries.

\subsection{The content of education is boring and the teaching form lacks new ideas.}

The textbook content of legal education is mainly based on basic principles and specific provisions of the constitution, laws and regulations. These contents are relatively abstract and difficult to attract students. In order to cope with the examination, students mainly memorize by rote and do not fully understand many contents in the provisions. At the same time, the teaching form is dominated by teachers' classroom teaching and the rhythm of the whole class is so consistent that students' attention concentration is not good and their learning efficiency is correspondingly low.

\subsection{Students have rebellious psychology and deliberately break the law.}

College students are at the moment of transition from youth to adulthood. At this time, there will be some fluctuations in students' psychology, and it is easy to generate violent emotional changes due to some information around them, which will eventually lead to the occurrence of crimes. There are also some students who do not know the consequences of breaking the law, and in order to gain attention from others or show their own personality, they deliberately break the law.

\subsection{The teachers have no social practice and the teaching content is empty and divorced from reality.}

Due to the uniqueness of the legal profession, teachers who teach legal education often do not have relevant social work experience, so their understanding of legal procedures, provisions and 
other situations basically comes from the theoretical knowledge they have learned. As a result, the teaching content of legal education is also based on written knowledge, and it is empty and divorced from reality, which does not help students in the application of the legal knowledge they have learned in real life, thus losing the value of legal education.

\section{The experience of foreign legal education}

Legal education has become one of the important contents in foreign basic education. In Britain, children's family education before school age of 10 has already involved the relevant content of the legal system; Japan even puts legal education above other education contents in order to cultivate the civil consciousness of national; The United States is a relatively mature legal country, and the effect of its legal education is relatively obvious. It takes legal education as a part of civic education, with teaching relevant contents from the aspects such as the origin, theoretical basis, operating principles, constitution, and civic rights and obligations of American law. The whole legal education process runs through the entire educational stage of the national, which lays a foundation for the cultivation of qualified social citizens.

Based on the practice of legal education in foreign colleges and universities, it can be seen that there are some identical characteristics, which are mainly manifested in the following aspects:

\subsection{Aim at the re-cultivation of political relations.}

Different from our country's concept of legal service for morality, foreign legal education aims at cultivating students' political concepts and strengthens the education of political system in legal teaching, so that students are being cultivated as new political relations in schools, in order to form the concept of citizens, understand their rights and obligations, exercise their power and fulfill their obligations in real life.

\subsection{Teaching is novel and diversified.}

In terms of teaching approach, American school education, British family education, and French social education are all responsible for legal education. At the same time, some countries of religious nature also use religious education to achieve the goal of legal education. In terms of teaching methods, the teacher-led form of classroom teaching has stepped down from the mainstream position, replaced by students' autonomous exploration, in which through participating in relevant activities in schools and communities, students understand and learn the content of the legal system. At the same time, the society and campus environment are the catalysts to enhance the effect of legal education. In order to realize socialization, the student will consciously conduct relevant legal education.

\subsection{Strengthen students' experience feeling of law.}

In foreign legal education, the state pays more attention to the experience feeling of education so as to prevent crimes. For example, students are organized to visit prisons and mortuary (death in violation of traffic regulations) to show the effectiveness of the law to influence and deter students, so that they can think about violations of the law before they are implemented, thus avoiding serious consequences.

\subsection{Combine theoretical teaching with practice.}

Unlike legal education in our country, foreign legal education pays more attention to the practicality of law, that is, it applies the legal and political knowledge learned to real life. In legal teaching, it also takes more common illegal behaviors in daily social activities to analyze them, so as to correspond to the application of legal concepts and help students skillfully use relevant laws when encountering problems.

\subsection{Encourage students to use the law to protect their rights.}

The advancement of foreign legal education lies in teachers' emphasis on the cultivation of the 
concept of student rights protection. When conducting teaching activities, teachers attach great importance to the legality of their own language and behaviors; as for the bullying and insulting problems that students encounter in school, teachers will encourage them to take legal means to end the continuation of these acts.

\section{Measures to improve the effect of legal education for college students}

In order to solve various problems of legal education in actual teaching in China, achieve the goal of legal education for college students, and train qualified social citizens, based on the relevant experience of foreign legal education mentioned above, the following measures can be obtained to improve the effect of legal education for college students:

\subsection{Construct an independent legal education system.}

In order to change the problem that the boundary between legal education and moral education is not clear, the construction of an independent system is the top priority of legal education. The content of legal education should be integrated to form a legal education system with the history of international legal development, China's constitution and political system, China's legal development and reform, legislative principles, law enforcement and other content as the main body, so as to enhance the political function of legal education.

\subsection{Reform the traditional education teaching method.}

In order to improve the teaching effect of legal education, traditional classroom cramming teaching should be replaced by scientific teaching methods. Various teaching methods, such as taskdriven teaching method, project-based learning teaching method, life teaching method, and interest teaching method should be systematically introduced into the classroom according to the characteristics of the teaching content of legal education so as to enable students to generate learning interest and change the situation of passive learning.

\subsection{Open up part-time teachers positions to professional legal talents.}

The lack of professional experience of teachers is an important reason why the legal education in colleges and universities is divorced from the social reality. Professional legal workers have come into contact with a large number of legal cases in their daily work and have already summed up certain rules and experiences. The absorption of these legal talents as part-time teachers and the extraction of an appropriate amount of class hours for them to teach legal practice courses are of great help to students in establishing awareness of the rule of law and understanding the relevant contents of laws and regulations.

\subsection{Increase various activities aimed at legal education.}

In order to help students realize the goal of combining theory with practice, the school should actively organize relevant campus or social activities, such as mock courts, constitutional knowledge questions and answers, visiting and studying in law firms, etc., to help students learn and understand relevant knowledge in legal education through practical application in reality, and to be able to apply the learned content in real life.

\subsection{Guide students' psychological problems in time.}

Aiming at the problem of psychological instability of college students, the school should set up psychological counseling or guidance positions, in which students' pressure can be released through talking. At the same time, legal education can be integrated into them, and it can be given in time before students' bad thoughts are converted into actions so as to maintain the safe and harmonious campus environment.

\subsection{Provide relevant legal support to students.}

As for the infringement acts students encounter in campus and life, through analyzing the case, 
teachers can teach them how to collect evidence, how to conduct legal procedures, and how to predict the final possible judgment results, which serve as legal support for students to encourage students to learn to seek legal approach to protect their own interests when encountering problems, thus achieving the goal of legal education.

\section{References}

[1] Y. Huang: Review of Higher Education, Vol. 6 (2018) No.2, p.45-49 (In Chinese)

[2] J. Hu: Journal of Teaching and Management, Vol. 30 (2013) No.27, p.30-32 (In Chinese)

[3] G.Z. Chen, G.H. Lin and X. Zhou: Legal System and Society, Vol. 22 (2013) No.5, p.216 (In Chinese)

[4] F. Ren, B.B. Chen and L. Huang: Journal of Jilin TV \& Radio University, Vol. 30 (2017) No.9, p.83-84 (In Chinese)

[5] S.M. Zhang: Legality Vision, Vol. 32 (2016) No.34, p.28-31 (In Chinese) 